\title{
Internet Financial Reporting in Malawi
}

\author{
Andrew Munthopa Lipunga ${ }^{1}$ \\ ${ }^{1}$ Department of Accountancy, University of Malawi-The Polytechnic Blantyre, Malawi \\ Correspondence: Andrew Munthopa Lipunga, Department of Accountancy, University of Malawi-The \\ Polytechnic, Private Bag 303, Chichiri, Blantyre 3, Malawi. E-mail: alipunga@poly.ac.mw
}

\author{
Received: March 3, 2013 \\ Accepted: April 4, 2014 \\ Online Published: May 22, 2014 \\ doi:10.5539/ijbm.v9n6p161 \\ URL: http://dx.doi.org/10.5539/ijbm.v9n6p161
}

\begin{abstract}
The dawn of Internet has resulting in the evolution of financial reporting from the conventional design of the printed annual report to the contemporary Internet Financial Reporting (IFR). Due to its growth, IFR has attracted the interest of researchers. However despite the fact that much research have been carried out, the understanding of the level of IFR is still vague. The study was an evaluation of the level of IFR focusing on a developing country, Malawi. The study used content analysis methodology and an IFR index in examining and measuring the level of IFR among the listed companies in Malawi. The study found that $92 \%$ of the sampled listed companies had a corporate website and $61.5 \%$ of the same were engaged in IFR however the overall IFR index was 0.28 indicating low level of IFR. Furthermore, the companies were generally using the traditional PDF format which lacks flexibility in terms of financial information manipulation that aid decision-making by the users. The results suggest underutilisation of IFR by the companies, thus more needs to be done to enhance IFR among the listed companies in Malawi. Preparers need to be aware of what IFR entails and the professional bodies need to provide the required guidance of the IFR framework.
\end{abstract}

Keywords: internet financial reporting (IFR), IFR index, Malawi

\section{Introduction}

Generally, information disclosure is unavoidable and of the essence in the modern business environment in order to circumvent possible issues linked with information asymmetry and agency problems (Momany \& Pillai, 2013). Companies are therefore striving for more transparency in communicating company information, ensuring good access to company information (Yap \& Saleh, 2011) by all stakeholders. Disclosure of material information aids investors in investment decision-making and influence prospective investors to invest in the company (Yap \& Saleh, 2011), and is also regarded as a signal for good corporate governance (Momany \& Pillai, 2013). Among various types of information the current study focuses on financial information which is basically disclosed through financial reports prepared by the companies. These reports play an essential role as they reflect the efficiency and effectiveness of the management of the organisation and the work being done by the organisation (Salawu, 2013).

According to Khan \& Ismail (2011a) up to a decade ago, the means of acquiring financial statement information was through the printed annual reports; consequently access to annual reports was limited through the libraries or analyst reports. Currently, companies can publish their financial information either by using paper-based reports or diverse electronic facilities (Momany \& Pillai, 2013). Among various potential electronic means, Internet is becoming a popular way of communicating to all stakeholders (Yap \& Saleh, 2011). According to CICA and CIRI (2008), Internet is now widely acknowledged as a key medium for disseminating business and financial information. Kumar \& Jain (2012) also recognised that its use is increasingly widespread, both by the public and the businesses as well. Joint stock companies are therefore utilising it to enhance transparency of their operations through the provision of useful financial and non-financial information (Pervan, 2005). Explaining the importance of the use of Internet, Agboola \& Salawu (2012) stated that the use of the Internet enables worldwide dissemination of information and thus facilitating the improved availability of financial information in particular, as a result investment is encouraged. As such, investors, analysts and others are accustomed to using the company websites to acquire the needed information (CICA \& CIRI, 2008).

The development of technology is what has contributed to turning Internet into a useful, fast and cost-effective tool for disseminating information to the shareholders (Lamani \& Çepani, 2011) and other stakeholders. Presently, the use of the Internet has provided a new way for companies to communicate with current and 
potential investors (Salawu, 2013). The internet is offering the potential for companies to reach a wider range of users without time limits, or boundaries (Khan, 2007). As a result it is creating excellent opportunities and the most effective way to publish financial information in conformity with requirements for transparency and the timely reporting (Lamani \& Çepani, 2011). This is the case because through the Internet, information can be presented very quickly and in more effective and efficient way, besides, information on the internet has many advantages as it is real time reporting, easily deployed, without restriction, current, has high interaction capabilities, and unlimited access to greater volume of data (Kumar \& Jain, 2012). Thus the major advantage of the Internet is its flexibility, which, however, that also creates a disadvantage for credibility and authenticity (Wagenhofer, 2003). It is however recognised that the benefits of Internet outweigh the disadvantages hence almost every company maintains its website, especially in developed countries as evidenced in literature (Salawu, 2013).

The development of Internet has resulting in the evolution of financial reporting from the conventional means of the printed annual reports to the modern Internet Financial Reporting (IFR) (Al-Htaybat et al., 2011). Though IFR is recent, it is a fast-growing phenomenon (Agboola \& Salawu, 2012). Many companies in developed and developing economies have website dedicated to communicating financial information to the investors (Yap \& Saleh, 2011). IFR is proving advantageous not only to the company but to all stakeholders. It is allowing companies to disseminate information to unidentifiable consumers, contrary to the paper-based annual report which communicates information to particular group (Agboola \& Salawu, 2012). With the Internet revolution, financial information is becoming public good with unrestricted global access, besides, firms are able to disclose disaggregated and incremental financial data and conventional annual reports with additional financial and non-financial information in multiple formats to wider audience (Agboola \& Salawu, 2012).

It is evident that IFR is more than a viable alternative to paper-based form of reporting (Salawu, 2013). However, at the moment Salawu (2013) noted that the content, extent and format of disclosure on the website are yet to be standardized as a result different companies are adopting different financial reporting practices. Momany \& Pillai (2013) also pointed out that although numerous companies worldwide publish their financial data on their websites, the quantity of information disclosure in reality varies among them; some publish comprehensive financial statements whereas others partial or summary financial statements or just financial highlights. Furthermore, despite the fact that much research has been carried out with regard to IFR, the understanding on the level of IFR is still generally vague (Khan \& Ismail, 2011a). Thus more research is needed focusing on understanding the level and format of IFR with the aim of improving and standardising the practice.

Therefore, there is a need to examine IFR in Malawi in order to understand its extent and the role of the Internet in communicating financial information; these will assist in finding out how that role may be enhanced (Agboola \& Salawu, 2012). The study was therefore aimed at empirically evaluating the extent of IFR focusing on a developing country, Malawi. To the best of the knowledge of the author the extent and forms of IFR by the quoted companies in Malawi is yet to be ascertained. Furthermore in harmony with Agboola \& Salawu (2012) it is also not clear whether Malawian companies are exploiting Internet to the fullest. The study extends the evidence of the extent IFR practices and in the process broadens the understanding of the same and enriches literature. Besides, the study informs the practitioners in Malawi of the status and gaps that needs filling in order to realise the benefit of IFR. The rest of the paper is structured as follows. The section two reviews the existing studies and followed by section three that discuses the research methodology. Section four presents the results and resultant discussion and finally section five gives the concluding remarks.

\section{Literature Review}

At present, the use of the Internet as a channel for disseminating corporate financial information has become an observable fact (Lamani \& Çepani, 2011). It is increasingly widespread for large corporations to disseminate information to their stakeholders using the Internet although it is still a voluntary disclosure medium (Khan \& Ismail, 2011b). Kumar and Jain (2012) attributed less cost and high benefits accruing to the companies as contributory factors to the increasing Internet use in communicating financial and non-financial information. As a result, websites of many companies have large amounts of information on a rich range of financial matters (Khan \& Ismail, 2011b) aiming at satisfy varying users' needs (Al-Htaybat et al., 2011). The usage of Internet in disseminating financial information has as a resulted attracted interest of numerous researchers. This section presents the prior studies dealing with the extent, content and presentation of IFR from different countries.

In Jordan, Momany and Al-Shorman (2006) investigated the extent of financial reporting on the internet of the companies in Jordan listed in the first market on Amman Stock Exchange for the year 2004. The results of the internet survey indicated that about $45 \%$ of companies had a corporate website. It was further revealed that $70 \%$ 
of the websites reported financial information while 30\% did not report any. It was further found that about $31.5 \%$ reported a comprehensive set of financial statements, $15.8 \%$ reported partial or summary financial statements, and (52.7\%) reported financial highlights. Similarly, Momany \& Pillai (2013) evaluated the extent of Internet Financial Reporting of the companies quoted on the Abu Dhabi Securities Exchange (ADX) in United Arab Emirates. The study sampled all 65 companies quoted on the first market of ADX. The companies were divided into ten sectors based on ADX classification. The results revealed that $89 \%$ of the quoted companies had websites while $11 \%$ had no websites. Furthermore it was found that $60 \%$ of the companies that had a website presented financial information on the websites while the remainder (40\%) did not present financial information on their web-sites.

Salawu (2013) endeavoured to determine the extent and form of internet financial reporting by the quoted companies in Nigeria. The results revealed that $90 \%$ (139) of the quoted companies 139 companies had websites while $10 \%$ (16) had no website. Sectoral analysis ranked financial sector highest as $98 \%$ of the companies in the sector had websites. Furthermore, the results revealed that out of the total of the 139 companies that had a website, only 77(55\%) disclosed financial information on their web pages with the remainder 62 (45\%) disclosing nothing. In Albania, Lamani and Çepani (2011) examined the extent and the nature of IFR focusing on banks and insurance companies. The findings of their descriptive analysis indicated that 24 out of 26 examined companies had websites; out of which 20 were providing financial information on their websites. In Croatia an investigation was also carried out on a basic sample of 38 joint stock companies quoted on Croatian bourses by Pervan (2005). The results showed that twenty of the companies made use of Internet financial reporting and eighteen had no such practice.

In Malaysia, Khan and Ismail (2011a) analysed the level of Internet financial reporting (IFR) by companies quoted on the Main Board of Bursa Malaysia. The results revealed that the level of IFR of quoted companies were within the range of $48.27 \%$ to $78.16 \%$ with a mean of $65.10 \%$. The results indicated that the overall level of IFR of the quoted companies was good. Still in Malaysia, Aziz et al. (2011) used scores in examining whether Malaysian companies well fully exploiting technology in financial reporting. The results showed that Malaysian companies were not fully exploiting the available technology in presenting the financial information to their users. This was indicated by the fact that $26 \%$ of the sampled companies scored within the range of $40 \%$ to $49 \%$ marks. Nevertheless, the overall results revealed that more than half of the companies (53\%) had above average score.

Dutta and Bose (2007) investigated how Internet is utilised to publish corporate information by the quoted companies of Bangladesh. The sample for the study consists of 268 companies quoted on the Dhaka Stock Exchange (DSE) and the Chittagong Stock Exchange (CSE). The study revealed that web-based corporate reporting in Bangladesh was still in its infancy. The results indicated that only $38.81 \%$ of 268 companies had a website. Furthermore the scoring scheme used in measuring the level of web-based corporate reporting revealed a wide variation in the level of web-based corporate reporting across 15 sectors, with Banking, Leasing \& Finance sector being the highest-ranked sector.

In relation to content and presentation of IFR on the other hand, Khan and Ismail (2012) attempted to study the items which are important in IFR from the view of annual report preparers. The study divided the level of IFR into two, namely content dimension and presentation dimension. The results showed that in relation to content dimension five most important items were: income statement of current year, balance sheet of current year, cash flow statement of current year, auditor report of current year, and annual report of current year (full text). On presentation dimension five most important items were: the length of time taken to download the company's website, PDF annual report format, hyperlink to financial analysis, the existence of hyperlink in the annual report and link to the website. Pervan (2005) found that the companies engaged in Internet financial reporting on the whole were publishing the annual reports together with the reports of their auditors. In addition, it was found that most of the companies were using the PDF format for the reports that they were publishing. Almilia \& Budisusetyo (2008) noted also that most IFR was confined to PDF, as such looked exactly like the paper-based annual reports. The same was also found by Dutta et al. (2010) and Davey and Homkajohn (2004).

Khan and Siang (2013) took another angle in identifying the important components of IFR by engaging the public investors from online forum in Malaysia. The components of IFR were compacted to 50 items only to represent the components in IFR for the purpose of optimization. The result of the study indicated that the top five components user's reading preference and usage are: (1) annual report, (2) dividend, (3) current share price, (4) balance sheet and (5) historical share price. On the contrary, the features deemed unnecessary in IFR consist of: (1) audio-visual (video) recording of meeting, (2) multilingual, (3) external links, (4) site map, and (5) corporate calendar. 
In conclusion, it is apparent that IFR has indeed attracted the attention of corporate reporting researchers, however according to Khan \& Ismail (2011a) the understanding on the level and factors influencing IFR is still vague. Furthermore, in other countries like Malawi there is hardly any research on the same. The current study contributes the filling of the existing research gap by providing empirical evidence of the extent of IFR in Malawi.

\section{Research Methodology}

Consistent with Aziz et al. (2011) and Momany and Pillai (2013) the population of the study comprised all the companies listed on Malawi Stock Exchange (MSE). Table 1 provide the list of all companies listed on MSE and their respective sectors. However, the sample consisted of only the companies whose primary operating environment is Malawi hence Old Mutual Limited was excluded, thus the sample was made up of thirteen (13) companies.

Table 1. List of companies listed on MSE and their sectors

\begin{tabular}{cll}
\hline No & Name of the companies & Industry/ Sector \\
\hline $\mathbf{1}$ & Blantyre Hotels Limited & Tourism \\
$\mathbf{2}$ & First Merchant Bank & Banking \\
$\mathbf{3}$ & Illovo Sugar & Agro-processing \\
$\mathbf{4}$ & Malawi Property Investment Co. Limited & Property Development \\
$\mathbf{5}$ & National Bank of Malawi & Banking \\
$\mathbf{6}$ & NBS Bank & Banking \\
$\mathbf{7}$ & NICO Holdings Limited & Financial \\
$\mathbf{8}$ & National Investment Trust Limited & Investment Trust \\
$\mathbf{9}$ & Press Corporation Limited & Conglomerate \\
$\mathbf{1 0}$ & Real Insurance Limited & Insurance \\
$\mathbf{1 1}$ & Standard Bank & Banking \\
$\mathbf{1 2}$ & Sunbird Tourism Limited & Tourism \\
$\mathbf{1 3}$ & Telekom Networks Limited & Telecoms \\
$\mathbf{1 4}$ & Old Mutual Limited* & Financial \\
\hline
\end{tabular}

The websites of the listed companies were browsed to collect data relating to financial reporting on the internet (Dutta \& Bose, 2007; Salawu, 2013). The www.google.com and www.yahoo.com were mainly used in searching the websites consistent with related studies (Momany \& Al-Shorman, 2006; Salawu, 2013). Furthermore in harmony with Momany \& Al-Shorman (2006) the listed companies were classified into three categories namely; companies that have a website and report financial information, companies that have a website and do not report financial information, and companies without a website. Kumar \& Jain (2012) recognised that financial information provided by the company through websites can include:

"a set of comprehensive financial statements, periodic disclosures, interim financial results, annual reports, including footnotes, partial financial statement and/or the subjects of financial information which may include dividend information, summary financial statements, financial highlights or anything resulting from such reports, the stock price data, market trends, analyst reports, discussions related to management operations, a database of companies' related news and events, and other company-specific information like information regarding subsidiary companies and mergers and acquisitions etc.'

Consistent with Dutta \& Bose (2007) a scoring methodology was used to measure the level of IFR by the companies. As a result an IFR index was used this was adopted from Khan and Ismail (2011a). The index consists of two main dimensions: content and presentation. According to Khan and Ismail (2011a) content dimension measures the type of information reported through the website, while the presentation dimension 
measures the usage of the latest display criteria in disseminating corporate information and the company's web design.

IFR index was computed by means of a checklist, which contains 80 items (see Appendix A). The study was in two steps; (1) searching the website and determine whether it was used to report any sort of financial information; and (2) the websites with financial information was scored. The scoring involved the examination of the website each company and awarding a score of " 1 " if an item on the checklist was found or a score of "0" if not found (Khan \& Ismail, 2011a). The following model was used to compute the IFR index:

$$
I F R \text { index }=\frac{\sum \text { real score obtained by the company }}{\sum \text { maximum score }}
$$

\section{Findings and Discussion}

This section presents the results of the search and content analysis of the corporate websites of the sampled listed companies in Malawi. It must be noted that using the IFR index adopted, range of score is between 0 and 1; 0 being the minimum and 1 being the maximum. This is both at item and company levels.

\subsection{Level of Internet Financial Reporting}

As is exhibited in Table 2, out of the 13 sampled listed companies, $12(92 \%)$ had websites and only 1 had no website. Furthermore, out of the 12 having a corporate website, $9(61.5 \%)$ report financial information on them while $4(30.8 \%)$ did not. The results indicate that $38.5 \%$ (5) of the sampled listed companies in Malawi do not practice Internet financial reporting while $61.5 \%$ are practicing.

Table 2. Website status of sampled companies

\begin{tabular}{lcc}
\hline & No. & $\mathbf{\%}$ \\
\hline Companies without a website & 1 & 7.7 \\
Companies that have a website and do not report financial information & 4 & 30.8 \\
Companies that have a website and report financial information & 8 & 61.5 \\
Total & $\mathbf{1 3}$ & $\mathbf{1 0 0 . 0}$ \\
\hline
\end{tabular}

Figure 1 exhibited the individual company scores; their rankings and the overall (mean) score of the eight companies that do practice internet financial reporting. As can be seen the highest score was 0.36 and the lowest was 0.21 and the overall (mean) score was 0.28 . It can further be seen that 4 companies scored average or below average and the other four (4) companies had above average scores. The results indicate generally low level of IFR practices among the listed companies in Malawi.

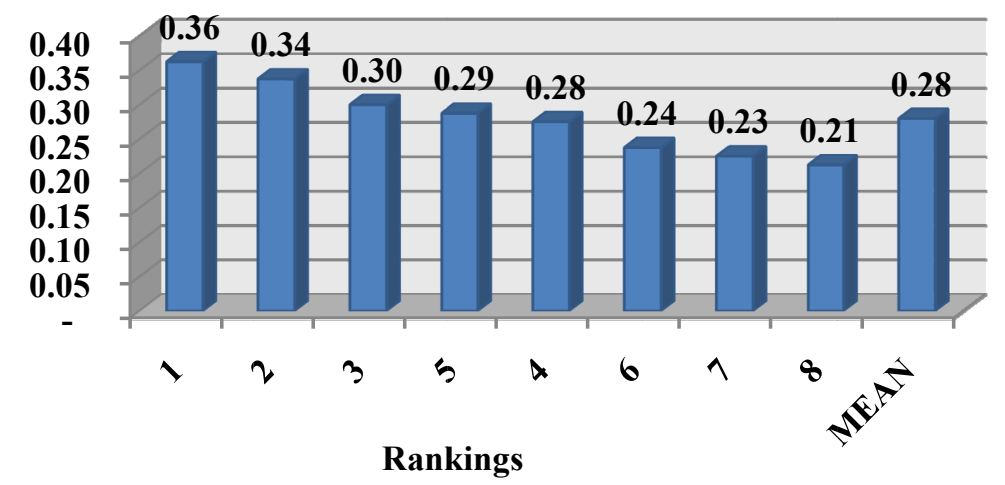

Figure 1. Individual and overall IFR scores 


\subsection{Analysis of the Disclosed Information}

\subsubsection{Content versus Presentation of IFR}

The IFR index was made up of 62 content related disclosure items and 19 relating to presentation (see Appendix A). Table 3 presents the results of analysis of these two categories. As can be seen, in relation to the content dimension, the lowest score was 0.18 and highest was 0.34 with the mean score of 0.25 . The scores indicates that the among the sampled companies the lowest disclosed on the internet $18 \%$ and the highest disclosed $34 \%$ of the 62 content related disclosure items. On the other hand, in relation to presentation dimension the lowest score was 0.26 and the highest was 0.47 with mean score of 0.36 . Indicating that the lowest company disclosed $26 \%$ and the highest disclosed $47 \%$ of the 19 presentation related disclosure items. The statistics indicates that in both of the dimensions the individual companies disclosed were less than half (50\%) of the items, suggesting poor performance in both dimensions by all the sampled companies.

Table 3. Analysis of the content and presentation scores

\begin{tabular}{lcccc}
\hline & Min & Max & Mean & Std. Dev. \\
\hline Content & 0.18 & 0.34 & 0.25 & 0.05 \\
Presentation & 0.26 & 0.47 & 0.36 & 0.07 \\
\hline
\end{tabular}

Furthermore, Table 4 gives the results of a paired test. The table exhibits the mean difference between content and presentation dimensions of (-0.10794). As can be seen the significance value is less than $0.05(0.001)$, indicating significant difference between content and presentation scores. Thus it can be concluded that the companies relatively placed more emphasis on presentation aspects of IFR than on the content aspects. And that poses a problem because, although presentation dimension is very important, placing relatively more focus on it is misplacement; it should rather be the opposite at worst and balanced at best. The results suggest the need for improvement in both dimensions however relatively more is need in the content dimension.

Table 4. Paired samples test

\begin{tabular}{|c|c|c|c|c|c|c|}
\hline & \multicolumn{3}{|c|}{ Paired Differences } & \multirow[t]{2}{*}{$\mathbf{t}$} & \multirow[t]{2}{*}{ df } & \multirow{2}{*}{$\begin{array}{c}\text { Sig. } \\
\text { (2-tailed) }\end{array}$} \\
\hline & Mean & $\begin{array}{c}\text { Std. } \\
\text { Deviation } \\
\end{array}$ & $\begin{array}{c}\text { Std. Error } \\
\text { Mean }\end{array}$ & & & \\
\hline Content of IFR - Presentation of IFR & -.10794 & .05477 & .01936 & -5.575 & 7 & .001 \\
\hline
\end{tabular}

\subsubsection{Item Score: Lowest and the Highest}

Table 5 and Table 6 present the lists of items with the lowest score of zero (0) and the highest/maximum score of one (1). As can be seen on Table 5, 40 items $(50 \%)$ had a zero (0) score, 33 in the content dimension and 7 in presentation dimension. The table indicate that all the key statements that make up the financial statements were not being reported on the Internet by the listed companies. These include income statements, statement of financial position (balance sheets), cash flow statements, statement of changes in equity and the notes to the accounts. As a result other important components of the annual report were also not being provided such as auditor's report, accounting policy and management report/analysis. It should however be noted that these statements were being provided as single package either as annual report or summary of the annual report. As per the checklist such provisions were items on their own right. 
Table 5. Items with a zero (0) IFR score

\begin{tabular}{|c|c|c|c|}
\hline \multicolumn{4}{|c|}{ Content } \\
\hline 1 & Income statement of current year & 18 & Auditor report of current year \\
\hline 2 & Balance sheet of current year & 19 & Changes in stockholders' equity in the current year \\
\hline 3 & Cash flow statement of current year & 20 & Summary of key ratios over a period of at least five years \\
\hline 4 & Auditor report of current year & 21 & Segmental reporting by line of business in past years \\
\hline 5 & Notes to financial statements of current year & 22 & Quarterly report of past years \\
\hline 6 & Statement of changes in shareholders' equity & 23 & Auditor signature in past years report \\
\hline 7 & Income statement of past years & 24 & Charters for the audit committee \\
\hline 8 & Accounting policy & 25 & Company's charter in the current year \\
\hline 9 & Balance sheet of past years & 26 & Information on corporate strategy \\
\hline 10 & Cash flow statement of current year & 27 & CEO signature in the report \\
\hline 11 & Auditor report of past years & 28 & Segmental reporting by region in current year \\
\hline 12 & Notes to financial statements of past years & 29 & Segmental reporting by region in past years \\
\hline 13 & Dividend information & 30 & Link to Malawi Stock Exchange website \\
\hline 14 & Quarterly report of current year & 31 & Indicator for finding current information directly \\
\hline 15 & Analyses of main business risks & 32 & Projected information \\
\hline 16 & Segmental reporting by line of business in current year & 33 & Information on intellectual capital \\
\hline 17 & Management report/analysis in current year & & \\
\hline \multicolumn{4}{|c|}{ Presentation } \\
\hline 1 & Hyperlinks inside the annual report & 5 & Hyperlinks texts \\
\hline 2 & Financial data in processable format (such as Excel) & 6 & Change to printing friendly format possible \\
\hline 3 & Use of multimedia technology (in general) & 7 & Annual report in HTML format \\
\hline 4 & Table of content & & \\
\hline
\end{tabular}

On the other hand, Table 6 shows that only 12 items (15\%) had the maximum score (1). Five were items in the content dimension and the other five in the presentation dimension. As can be seen on the table, all these items though were important aspects of IFR they are peripheral to the actual intent of financial reporting. Consistent with Khan and Siang (2013) the results further indicates the need for the preparers of IFR to consider enhancing the presentation and content of IFR.

Table 6. Items with the maximum score (1)

\begin{tabular}{ll}
\hline \multicolumn{1}{c}{ Content } \\
\hline 1 & Web page in English \\
2 & Financial Reporting Standard (FRS) basis in the current year \\
3 & Corporate information \\
4 & Members of the Board of Directors \\
5 & Users quickly find the financial information \\
6 & Current year information can be distinguished from last year's information \\
7 & Current press releases or news \\
\hline & \multicolumn{1}{c}{ Presentation } \\
\hline 1 & Ability to download reports \\
2 & Direct e-mail contacts (feedback) available \\
3 & Internal search engine \\
4 & Clear boundaries for annual reports \\
5 & Menu pull-down \\
\hline
\end{tabular}




\subsection{Format of IFR Information}

According to Pervan (2005) the financial data can be published in various forms i.e. HTML, PDF and XLS. However, the study found that the format used by the listed companies was the traditional PDF. Generally the basic advantage of the PDF format according to Pervan (2005) is that the hardcopy of the document will exactly reproduce that which found on the Internet. Furthermore, according to Wagenhofer (2003) PDF format can be interpreted as assuring the Internet user of the boundaries and quality of the information. However, PDF format is static thus it lacks comprehensive use of various other formats as well as active application of the new XBRL technology (Lamani \& Çepani, 2011), thus it has some limited ability to interact with Internet technologies (Smith and Pierce, 2005). Furthermore, the format cannot be used therefore for manipulating financial data useful in making decisions (Dutta \& Bose, 2007). Format like XLS is said to be a very suitable format for the publication of data, as it enables direct calculation of various indicators and the use of numerous mathematical and statistical functions (Pervan, 2005).

Thus consistent with Smith \& Pierce (2005) the evidence from the study indicates that preparers regard IFR as a channel for distributing existing printed material, thus the nature, format and content of disclosure does not significantly differ from paper-based disclosures. The use of mainly PDF format may be due to lack of effective awareness of what IFR entails and its benefits to the companies and their stakeholders. As asserted by CICA \& CIRI (2008) internet of offers opportunity to utilise diverse technologies in the provision of information in new and meaningful ways. Furthermore, according to Wagenhofer (2003) Internet financial reporting is not restricted to static texts and graphs, the users should be able to search, filter, retrieve, download, and even reconfigure such information at low cost in a timely fashion. Thus Dutta and Bose (2007) recommended IFR presentation using processable format so that users of financial information can manipulate financial data so as to make useful decisions. At the moment IFR is being under-utilised (Salawu, 2013) and consistent with Dutta \& Bose (2007) is in infancy in Malawi.

\section{Conclusion}

Pervan (2005) posited that considering the constant growth in the number of Internet users, investing in Internet financial reporting could be a useful decision for joint stock companies aspiring for the enhancement of transparency of their operations. Undeniably, the Internet is offering an excellent opportunity to companies for the enhancement of reporting to investors and other stakeholders and for presentation of more information for better analysis (CICA \& CIRI, 2008). The study has evaluated the extent of IFR in Malawi using the case of the listed companies. The study has found low level of IFR among the listed companies which may generally be due to comprehensive awareness of its benefits both to the companies and their stakeholders. The results suggest the need for enhancement of IFR among the listed companies in Malawi.

At the moment a number of recommendations have been made for the promotion of IFR. Agboola and Salawu (2012) recommended to both regulatory and professional bodies to jointly provide a template for Internet Financial Report to promote uniformity in financial information disclosure by companies. Salawu (2013) recommended to the Government and stock market regulators to come up with the regulatory framework for internet financial reporting and to require the release of both the online report and hard copy promptly. Lamani and Çepani (2011) recommended also oversight bodies to complete the special IFR regulatory framework. Lamani \& Çepani (2011) cited that these regulatory guidelines would direct companies to be more efficient in publishing financial information by stipulating such information in a standard format and in a timely manner so as to achieve comparability and reliability of the published data. Perhaps Malawi can borrow a leaf from these recommendations in order to enhance its image worldwide thus improving her ability to attract the need foreign investment.

The study had some limitations that include the fact that it was generally a cross-sectional examination, according to Yap and Saleh (2011) a longitudinal study can assist in shedding more light on the evolving process of web-based disclosure practices and their adoption. Future studies should consider adopting a longitudinal approach. Furthermore, the study evaluated the websites of listed companies only, thus the results may not be generalised to other unlisted companies. Future studies should also consider incorporating unlisted companies so as have a comprehensive view of IFR practice in Malawi.

\section{References}

AbuGhazaleh, N. M., Qasim, A., \& Roberts, C. (2012). The Determinants of Web-Based Investor Relations Activities by Companies Operating in Emerging Economies: The Case of Jordan. The Journal of Applied Business Research, 28(2), 209-226. Retrieved from http://journals.cluteonline.com/index.php/JABR/article/view/6842 
Agboola, A. A., \& Salawu, M. K. (2012). The Determinants of Internet Financial Reporting: Empirical Evidence from Nigeria. Research Journal of Finance and Accounting, 3(11), 95-105. Retrieved from $\mathrm{http}: / /$ www.iiste.org/Journals/index.php/RJFA/article/view/3817

Al-Htaybat, K., Alberti-Alhtaybat, L. V., \& Hutaibat, K. A. (2011). Users' Perceptions on Internet Financial Reporting Practices in Emerging Markets: Evidence from Jordan. International Journal of Business and Management, 6(9), 170-182. http://doi.dx.org/10.5539/ijbm.v6n9p170

Ali Khan, M. N. A., \& Siang, L. H. (2013). Public investor perception towards internet financial reporting in Malaysia. Retrieved from http://worldconferences.net/journals/wcik/paperwcik/WCIK\%20056Dr.\%20Mohd\%20Noor\%20Azli\%20bi n\%20Hj.\%20Ali\%20Khan.pdf

Ali Khan, M. N. A. B., \& Ismail, N. A. B. (2011a). The Level of Internet Financial Reporting of Malaysian Companies. Asian Journal of Accounting and Governance, 2, 27-39. Retrieved from http://www.ukm.my/ajag/vol2ch3.pdf

Ali Khan, M. N. A. B., \& Ismail, N. A. B. (2011b). The use of disclosure indices in internet financial reporting research. Journal of Global Business and Economics, 3(1), 157-173. Retrieved from http://www.globalresearch.com.my/journal/business_v03n01/0012_Article_462_Final_PG157_173.pdf

Ali Khan, M. N. A., \& Ismail, N. A. (2012). An empirical study on the indexes of internet financial reporting: The case of Malaysia. African Journal of Business Management, 6(5), 2086-2100. http://doi.dx.org.10.5539/10.5897/AJBM11.1596

Almilia, L. S., \& Budisusetyo, S. (2008). Corporate Internet Reporting of Banking Industry and LQ45 Firms: An Indonesia Example. $\quad$ Retrieved from http://www.almilia.com/wp-content/uploads/2008/08/corporate-internet-reporting-banking-lq-45.pdf

Aziz, A. A., Ariffin, N. N. M., \& Mohamed, I. S. (2011). Internet Financial Reporting in Malaysia. Retrieved from http://www.ipcsit.com/vol3/053M043.pdf

CICA \& CIRI. (2008). Financial and Business Reporting on the Internet: A Discussion Brief. Retrieved from http://www.cica.ca/publications/list-of-publications/manual/item12823.pdf

Davey, H., \& Homkajohn, K. (2004). Corporate Internet Reporting: An Asian Example. Problems and Perspectives in Management, 2, 211-227. Retrieved from $\mathrm{http}: / /$ www.businessperspectives.org/journals_free/ppm/2004/ppm_en_2004_02_Davey.pdf

Dutta, P., \& Bose, S. (2007). Web-based Corporate Reporting in Bangladesh: An Exploratory Study. The Cost and Management, 35(6), 29-45. Retrieved from http://papers.ssrn.com/sol3/papers.cfm?abstract_id=1098741

Dutta, P., Bose, S., \& Biswas, K. K. (2010). Corporate Financial Reporting on the Internet: Evidence from Bangladesh. The Cost and Management, 19-24. Retrieved from http://papers.ssrn.com/sol3/papers.cfm?abstract_id $=1965462$

Khan, T. (2007). Internet financial reporting: Disclosure about companies on websites. Journal of Business Systems, Governance and Ethics, 2(2), 37-46. Retrieved from http://www.jbsge.vu.edu.au/issues/vo102no2/khan.pdf

Kumar, P., \& Jain, S. K. (2012). Corporate financial reporting on internet-A study of BSE Sensex companies. Pacific Business Review International, 4(3), 65-72. Retrieved from http://www.pbr.co.in/vol4iss3/pbr\%20vol\%204\%20issue\%203\%2864-72\%29.pdf

Lamani, D., \& Çepani, L. (2011). Internet Financial Reporting by banks and insurance companies in Albania. The Romanian Economic Journal, 15(42), 159-174. Retrieved from http://www.rejournal.eu/Portals/0/Arhiva/JE\%2042/Cepani.pdf

Momany, M. T., \& Al-Shorman, S. A. (2006). Web-Based Voluntary Financial Reporting of Jordanian Companies. International Review of Business Research Papers, 2(2), 127-139. Retrieved from http://www.bizresearchpapers.com/Munther.pdf

Momany, M. T., \& Pillai, R. (2013). Internet Financial Reporting in UAE-Analysis and Implications. Global Review of Accounting and Finance, 4(2), 142-160. Retrieved from http://www.wbiconpro.com/106-Munder.pdf 
Pervan, I. (2005). Financial Reporting on the Internet and the Practice of Croatian Join Stock Companies Quotes on the Stock Exchanges. Financial Theory and Practice, 29(2), 159-174. Retrieved from http://hrcak.srce.hr/file/9236

Salawu, M. K. (2013). The Extent and Forms of Voluntary Disclosure of Financial Information on Internet in Nigeria: An Exploratory Study. International Journal of Financial Research, 4(1), 110-119. http://dx.doi.org/10.5430/ijfr.v4n1p110

Smith, B., \& Pierce, A. (2005). An Investigation of the Integrity of Internet Financial Reporting. The International Journal of Digital Accounting Research, 5(9), 47-78. http://www.uhu.es/ijdar/10.4192/1577-8517-v5_2.pdf

Wagenhofer, A. (2003). Economic consequences of internet financial reporting. Schmalenbach Business Review, 55(4), 262-279. Retrieved from http://www.sbr-online.de/pdfarchive/einzelne_pdf/sbr_2003_oct-262-279.pdf

Yap, K., \& Saleh, Z. (2011). Internet Financial Reporting in Malaysia: The Preparers' View. Asian Journal of Finance \& Accounting, 3(1), 138-161. http://dx.doi.org/10.5296/ajfa.v3i1.1067

\section{Appendix A}

\begin{tabular}{|c|c|c|}
\hline \multicolumn{3}{|c|}{ List of items making up the IFR index and Scores } \\
\hline \multicolumn{2}{|c|}{ Content } & \multirow{2}{*}{$\begin{array}{l}\text { IFR } \\
\text { Score } \\
0.00\end{array}$} \\
\hline 1 & Income statement of current year & \\
\hline 2 & Balance sheet of current year & 0.00 \\
\hline 3 & Cash flow statement of current year & 0.00 \\
\hline 4 & Auditor report of current year & 0.00 \\
\hline 5 & Annual report of current year (full text) & 0.88 \\
\hline 6 & Notes to financial statements of current year & 0.00 \\
\hline 7 & Statement of changes in shareholders' equity & 0.00 \\
\hline 8 & Income statement of past years & 0.00 \\
\hline 9 & Web page in English & 1.00 \\
\hline 10 & Accounting policy & 0.00 \\
\hline 11 & Balance sheet of past years & 0.00 \\
\hline 12 & Cash flow statement of current year & 0.00 \\
\hline 13 & Annual report of past years (full text) & 0.88 \\
\hline 14 & Financial Reporting Standard (FRS) basis in the current year & 1.00 \\
\hline 15 & Auditor report of past years & 0.00 \\
\hline 16 & Notes to financial statements of past years & 0.00 \\
\hline 17 & Dividend information & 0.00 \\
\hline 18 & Quarterly report of current year & 0.00 \\
\hline 19 & Analyses of main business risks & 0.00 \\
\hline 20 & Segmental reporting by line of business in current year & 0.00 \\
\hline 21 & Corporate information & 1.00 \\
\hline 22 & Half-year report of current year & 0.38 \\
\hline 23 & Management report/analysis in current year & 0.00 \\
\hline 24 & Auditor report of current year & 0.00 \\
\hline 25 & Changes in stockholders' equity in the current year & 0.00 \\
\hline 26 & Chairman's report & 0.13 \\
\hline
\end{tabular}




\begin{tabular}{|c|c|c|}
\hline 27 & Summary of annual report of current year & 0.38 \\
\hline 28 & Members of the Board of Directors & 1.00 \\
\hline 29 & Summary of financial data over a period of at least five years & 0.13 \\
\hline 30 & Top 10 stockholders in current year & 0.88 \\
\hline 31 & Financial ratios & 0.13 \\
\hline 32 & Half-year report of past years & 0.50 \\
\hline 33 & Summary of key ratios over a period of at least five years & 0.00 \\
\hline 34 & Segmental reporting by line of business in past years & 0.00 \\
\hline 35 & Users quickly find the financial information & 1.00 \\
\hline 36 & Quarterly report of past years & 0.00 \\
\hline 37 & Auditor signature in past years report & 0.00 \\
\hline 38 & Charters for the audit committee & 0.00 \\
\hline 39 & Company's charter in the current year & 0.00 \\
\hline 40 & Corporate social responsibility report & 0.75 \\
\hline 41 & Company address & 0.75 \\
\hline 42 & Information on corporate strategy & 0.00 \\
\hline 43 & Current year information can be distinguished from last year's information & 1.00 \\
\hline 44 & Directors shareholding information & 0.13 \\
\hline 45 & Annual report of current year (excerpt) & 0.25 \\
\hline 46 & CEO signature in the report & 0.00 \\
\hline 47 & Sales of key products & 0.13 \\
\hline 48 & Annual general meetings information & 0.25 \\
\hline 49 & Segmental reporting by region in current year & 0.00 \\
\hline 50 & Annual report of past years (excerpt) & 0.25 \\
\hline 51 & Segmental reporting by region in past years & 0.00 \\
\hline 52 & Code of conduct and ethics for directors, officers and employee & 0.25 \\
\hline 53 & Link to Malawi Stock Exchange website & 0.00 \\
\hline 54 & Indicator for finding current information directly & 0.00 \\
\hline 55 & Information about managers, at least the identity and curriculum vitae of executives & 0.38 \\
\hline 56 & Projected information & 0.00 \\
\hline 57 & Information on intellectual capital & 0.00 \\
\hline 58 & Current year resolutions of shareholders' meeting & 0.13 \\
\hline 59 & Historical share prices & 0.13 \\
\hline 60 & Current press releases or news & 1.00 \\
\hline 61 & Corporate governance principles/guidelines & 0.88 \\
\hline \multicolumn{3}{|c|}{ Presentation } \\
\hline 1 & Annual report in PDF format & 0.88 \\
\hline 2 & Hyperlinks to financial analysts & 0.13 \\
\hline 3 & Hyperlinks inside the annual report & 0.00 \\
\hline 4 & Link to homepage & 0.25 \\
\hline 5 & Link to top homepage & 0.25 \\
\hline 6 & Ability to download reports & 1.00 \\
\hline 7 & Link to table of contents & 0.13 \\
\hline
\end{tabular}




\begin{tabular}{lll}
\hline 8 & Direct e-mail contacts (feedback) available & 1.00 \\
9 & Financial data in processable format (such as Excel) & 0.00 \\
10 & Use of multimedia technology (in general) & 0.00 \\
11 & Table of content/sitemap & 0.00 \\
12 & Hyperlinks texts & 0.00 \\
13 & Hyperlinks to data on a third-party's website & 0.13 \\
14 & Change to printing friendly format possible & 0.00 \\
15 & Format of reports suitable for calculations & 0.13 \\
16 & Internal search engine & 1.00 \\
17 & Clear boundaries for annual reports & 1.00 \\
18 & Annual report in HTML format & 0.00 \\
19 & Menu pull-down & 1.00 \\
\hline
\end{tabular}

\section{Copyrights}

Copyright for this article is retained by the author(s), with first publication rights granted to the journal.

This is an open-access article distributed under the terms and conditions of the Creative Commons Attribution license (http://creativecommons.org/licenses/by/3.0/). 